\title{
Childbirth care after the implementation of the Carioca Stork Program: the perspective of nursing
}

\author{
Assistência ao parto após a implementação do Programa Cegonha Carioca: a perspectiva da \\ enfermagem
}

\section{Atención al parto después de la aplicación del Programa Cigüeña Carioca: perspectiva de la enfermería}

Ana Elisa Fernandes Lima ${ }^{1}$, Leila Justino da Silva ${ }^{1}$, Marianne de Lira Maia ${ }^{1}$, Adriana Lenho de Figueiredo Pereira ${ }^{1}$, Marcele Zveiter ${ }^{1}$, Tânia Maria de Almeida Silva ${ }^{1}$

Objective: to describe the actions recommended by the Carioca Stork Program for assistance to pregnant women and identify whether the implementation of this program had repercussions on the assistance from the perspective of the nursing team. Methods: descriptive study with a qualitative approach, conducted in a public maternity hospital. Semi-structured interviews were conducted with four obstetric nurses and seven nursing auxiliaries who work at the obstetric center of this maternity hospital. We used the technique of thematic content analysis. Results: the study categories were: Qualification of the hospital obstetric care, care and professional repercussions from the Carioca Stork Program. Conclusion: the nursing staff considered that the implementation of the program brought improvements in childbirth care, favored women's rights and the performance of obstetric nursing in the municipal health network.

Descriptors: Women's Health; Humanizing Delivery; Nursing Care.

Objetivo: descrever as ações preconizadas pelo Programa Cegonha Carioca para a assistência às parturientes e identificar se a implementação deste Programa teve repercussão nesta assistência, na perspectiva da equipe de enfermagem. Métodos: pesquisa descritiva com abordagem qualitativa, conduzida em uma maternidade. Foram realizadas entrevistas semiestruturadas com quatro enfermeiras obstétricas e sete auxiliares de enfermagem que atuam no centro obstétrico desta maternidade. Utilizou-se a técnica da análise de conteúdo temática. Resultados: as categorias do estudo foram: Qualificação da assistência obstétrica hospitalar e Repercussões assistenciais e profissionais do Programa Cegonha Carioca. Conclusão: a equipe de enfermagem considerou que a implementação do Programa provocou melhorias na assistência ao parto, favoreceu a garantia dos direitos da mulher e a atuação da enfermagem obstétrica na rede municipal de saúde.

Descritores: Saúde da Mulher; Parto Humanizado; Assistência de Enfermagem.

Objetivo: describir las acciones recomendadas por el Programa Cigüeña Carioca para atención a las parturientes y determinar si la aplicación de este Programa tuvo repercusiones en esta asistencia desde la perspectiva del equipo de enfermería. Métodos: estudio descriptivo, con abordaje cualitativo, realizado en una maternidad pública. Entrevistas semiestructuradas se realizaron con cuatro enfermeras obstétricas y siete auxiliares de enfermería que trabajan en el centro de obstetricia de la maternidad. Se utilizó la técnica de análisis de contenido temático. Resultados: las categorías del estudio fueron: Calificación de la atención obstétrica hospitalaria y Repercusiones asistenciales y profesionales del Programa Cigüeña Carioca. Conclusión: el personal de enfermería consideró que la aplicación del Programa ha traído mejoras en la atención al parto, favoreciendo la garantía de los derechos de la mujer y el cumplimiento de la enfermería obstétrica en la red de salud municipal.

Descriptores: Salud de la Mujer; Parto Humanizado; Atención de Enfermería.

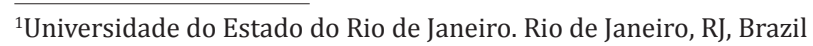




\section{Introduction}

The purpose of this study fits into the context of the recent implementation of the Carioca Stork Program by the Municipal Health Secretariat of Rio de Janeiro in 2011. This program aims to: eradicate the pilgrimage of pregnant women who look for childbirth care; reduce the maternal mortality rate; maintain the downward trend in neonatal mortality; humanize care during labor and birth; reduce preventable complications; improve the quality of maternal and newborn care indicators ${ }^{(1)}$.

To achieve these goals, the program defends that pregnant women should be informed in advance about the place they will give birth, make tours to know the institution where they will give birth, participate in educational activities and have ambulances for transportation to the reference maternity in the childbirth moment. To do so, three modules or programmatic components were provided: 1) Prenatal; 2) Welcoming with risk classification and 3) Mobile care ${ }^{(1)}$.

The Carioca Stork Program was officially launched in March 2011. However, in 2010, there was a pilot project with actions developed in primary care services and selected hospitals in accordance with the administrative regions.

In 2011 it was also launched the Stork Network by the federal government. Both government program strategies aim to qualify the maternal and child care and act on the causes of maternal mortality related to the period of pregnancy, childbirth or postpartum period. Such causes of maternal death, called direct, are the result of hypertensive disorders, abortion, inadequate treatment, unnecessary interventions, omissions and failures in the service network. The Stork Network was created aiming to face the obstacles present in the care network linked to quality of care and to women's care in the services of obstetric care ${ }^{(2)}$.

Such actions had already been taken in the National Pact for the Reduction of Maternal and Neonatal Mortality in 2004, but problems in the quality of prenatal care persisted, although access is practically universal. The diagnostic support network for the examinations that are recommended during pregnancy did not always contemplate the need of municipalities and in many places women still had to wander in search of a health facility to give birth $^{(2)}$. Moreover, there was the need of government intervention for the transformation of the attention offered to women and newborns in the country ${ }^{(3)}$.

In addition to this problem, Brazil committed itself to reduce maternal mortality and other health problems of its population in order to meet the goals set out in the eight Millennium Development Goals, set by the United Nations in 2000. The proposition of these objectives represented the largest international consensus for the development of humanity and should be achieved by the signatory countries. Specifically the fifth goal aims to reduce by three quarters the maternal mortality rate by 2015 . This same goal is aimed to fight the growth of cancer mortality for breast and cervical cancer ${ }^{(2)}$.

In recent years Brazil has advanced in improving the quality of care during labor and birth as a result of a series of efforts and initiatives of the government and society. However, the reduction of maternal and infant morbidity and mortality, particularly early neonatal, remains a serious problem ${ }^{(2)}$.

The organization and the qualification of assistance to prenatal, childbirth, birth and newborn care are key strategies to reduce mortality rates in this segment of health care. In the city of Rio de Janeiro, these indices have shown a well-established decline in recent years, but there is a need for progress to accelerate even more this reduction as well as to improve obstetric and neonatal care ${ }^{(1)}$.

The Carioca Stork Program is guided in the organization and definition of the reference hospitals since prenatal care, including the transportation of pregnant women at the time of labor, from their household to the maternity chosen during prenatal care, through two components: telephone service and ambulance service. From the definition of reference 
maternity and of the orientation to recognize the signs of labor, the pregnant women should call this telephone service, which defines the sending of an ambulance for pregnant women classified as low obstetric risk and their transportation to the reference maternity hospital. In these ambulances there are only nurses, who are responsible for care ${ }^{(1)}$.

The welcoming module aims at the reception of pregnant women in reference hospitals by the nursing staff, as well as the classification of obstetric risk, in order to guarantee health rights provided by the National Health System and the completion of strategies for the reduction of maternal and infant mortality. In this module, there is another stimulus action for pregnant women to engage in prenatal care, which is the distribution of a bag with baby clothes for the pregnant women who are enrolled in the $\operatorname{program}^{(1)}$.

Despite the fact that the Carioca Stork program does not provide a specific component to childbirth care, its actions are directly connected with this moment, since they try to improve the connection of primary care, where prenatal care is performed, with secondary care, where labor is assisted. It is part of the proposition of the Carioca Stork Program to reduce the pilgrimage of pregnant women in search of places to give birth; ensure referral and transportation to the reference maternity; promote prior visits to the pregnant women to know the maternity, when they are also oriented about the moment of childbirth, by the nurses of the institution; receive and classify obstetric risk, by nurses when a woman comes to an emergency room or to a hospital. Therefore, we consider it necessary to investigate whether these implemented actions reached the goals to qualify and humanize obstetric care given to pregnant women in the municipal maternity hospitals of Rio de Janeiro.

From these considerations, it was delimited as the object of study the assistance to women in delivery after the implementation of the Carioca Stork Program. The questions that guided the study were: What are the actions recommended by the
Carioca Stork program to take care of women during childbirth, according to the nursing staff? How does the team see this assistance after the implementation of this program?

The research aimed to describe the actions recommended by the Carioca Stork Program for assistance to pregnant women and to identify whether the implementation of this program had repercussions in this assistance from the perspective of the nursing team.

\section{Method}

This is a descriptive study with a qualitative approach, performed at a public maternity hospital in the city of Rio de Janeiro where the actions of the carioca stork program have been implemented since March 2011. This maternity hospital is located in the northern part of this city, attending both women with pregnancies classified as with low obstetric risk and those who received obstetric risk rating. According to institutional data, in 2012, 6,120 babies were born alive. Of these, 3,864 were born by normal delivery, and 789 of these attended by nurses.

Study participants were eleven members of the nursing staff from the day service, being four nurses and seven nursing technicians/assistants, who started working at the obstetric center of the maternity before the implementation of the Carioca Stork Program. One excluded from the study nursing team members who came to exercise their responsibilities in this maternity sector after the implementation of the program.

Data were collected in October and November 2014. Its achievement occurred with the use of the semi-structured interview technique, whose script consisted of two closed and five open questions. The interviews were conducted outside the healthcare environment, in the staff resting room, in order to avoid disruptions and possible constraints of the research participants or the patients attended.

For the analysis of the results it was applied the thematic content analysis technique, which is divided 
into three stages: 1) pre-analysis; 2) exploration of the material and treatment of results; 3) inference and interpretation ${ }^{(4)}$. To protect and guarantee the anonymity of the participants, the interviews were coded as: Interview 1 (I1); Interview 2 (I2), and so on.

The ethical principles of research were respected and the research was approved by the Research Ethics Committee of the Municipal Health Secretariat of Rio de Janeiro through the opinion No. $185 \mathrm{~A} / 2012$.

\section{Results}

The analysis of the testimonies of the nursing team made it possible to build two themes: Qualification of the hospital obstetric care; Welfare and Professional implications of the Carioca Stork Program.

\section{Qualification of the hospital obstetric care}

This thematic category includes the following topics: improving nursing care for women during childbirth, guided tour of the reference maternity and guidelines for delivery. Improving assistance was the most representative theme in the interview contents, followed by guided tour and guidance for childbirth.

The perception of the staff about the improvements in nursing care can be seen in the following excerpts from the interviews: We try to notice the woman in this environment... to respect the woman in her essence (I2). Respect for the bond between mothers and their newborns... that is the moment of power exchange, the moment of the release of oxytocin (I2). We try to break with the hegemonic biomedical model (I3).

The guarantee of access to the reference maternity hospital and the guided tour at the place where the birth will be assisted were considered fundamental strategies of the Carioca Stork Program to qualify the care of pregnant women and to promote safety for these women, reducing their pilgrimage on the occasion of their children's birth, as mentioned in the following testimonies: When they pay visits, they [pregnant women] come to know where childbirth will be made, to whom they have to report if they have any questions (I1). The pregnant women's access was better and easier (I8). They feel good because the [Carioca] Stork [Program] will get them at home, they have assistance at home until they get here [in the hospital] (I7).

Regarding the guidelines that the women receive during the maternity visits, the nursing staff referred to them as follows: These [guided] visits of the [Carioca] Stork [Program] are important because they will talk about labor, about what she will realize in her body, which is a contraction... Then she comes from home with that experience, with a better experience. It is much easier (I2). These women come to visit the maternity hospital with an average of 28 to 34 weeks [of pregnancy] and they know the structure, they usually look at our faces.... that face recognition (I3). There are guidelines about labor and delivery... orientations about the doubts they bring [for the guided tour] (I4). Guidelines in relation to labor, to care technologies.... She [the woman] has to be always informed (I2).

\section{Assistance and professional repercussions of the Carioca Stork Program}

In this thematic category emerged the following topics: Guarantee of women's rights, strengthening of obstetric nursing, women's satisfaction with the care and continuing care challenges.

The implementation of the Carioca Stork program led to greater respect for women's rights, such as presence of a partner and opportunity to exercise leadership during labor. This theme was the one that obtained the highest representation in the record of interviews. The nursing staff expressed this impact as follows: When they arrive, the first thing we say is that they have the right to have a companion (I11). We try to understand the moment of that woman in this environment, to respect the moment of that woman... to respect that woman in her essence (I2).

The nursing staff also considers that the implementation of the Carioca Stork program contributed to changes in perceptions and attitudes of women during delivery care in the delivery room, as mentioned in the following: So many have come after the 
visit of the [Carioca] Stork [Program] with a change in their eyes, as the birth ... when they come to childbirth care itself, they already have another view (E3).

The institution of the Carioca Stork Program also strengthened the role of obstetric nursing, perceived as strategic to improve the quality of care and the humanization of delivery, as it is highlighted in the following lines: What has changed is that we have more obstetric nurses, which was previously a minority, as there are more nurses nowadays to provide humanized vaginal delivery (19). They [the mothers] will be accompanied by obstetric nurses and they do the whole procedure, a follow-up treatment, a humanized delivery. They suggest walking, bathing during labor, understanding and participating in that moment, in order to understand that labor is not suffering, it is not torture, but that it is part of the whole process... (I10).

When talking about how to approach and welcome a woman, taking her as someone who has rights to be respected, the interviewees showed that roles are changing in obstetric care: By knowing this Carioca Stork program, they [women] end up knowing that they have performance in obstetric nursing and then, they seek the nurse (I2). When pregnant women prefer to have their delivery done by a nurse, I think it diminishes the centrality of doctors because, until now, doctors were seen as the centerpiece and now they're not anymore! (I11).

The contact and interaction with women who participate in the program contributed to the reflection on the results expressed in the daily attendance of delivery and birth, as seen in the following statements: Before, they [the women] were very disoriented ...I think they [the professionals] should welcome more the patients, guiding them more... (19). I notice that women already have a preparation during labor. They are already oriented about the presence of companions, about breastfeeding and about the freedom of position [maternal] during childbirth (I4).

This survey also revealed that there are still many challenges to be overcome in the context of obstetric care in the public health network, despite improvements perceived by the nursing staff: Many of them [women] did not even have prenatal care, and this happens still nowadays, obviously (I10). I still notice that many women do not arrive so well informed and we end up receiving those who are not [registered in the] [Carioca] Stork [Program]. I think it might be improved even more (I2).

There were also reports about lack of change in the activities developed by the nursing staff after the implementation of the Carioca Stork Program, as mentioned in the following statement: For us nothing changed, in fact this treatment was already done, what happens today was done prior to this program [Carioca Stork] (I10).

\section{Discussion}

The humanized care model has been an important component in the improvement of obstetric care, contributing to the important role of women and making childbirth a natural moment. Nursing has contributed to the adoption of humanized care in this assistance, which aim at minimizing interventions in the physiological processes involved in giving birth and being born, fostering interpersonal relationships between professionals and women, respecting the individuality, encouraging welcoming and increasing the bond mother-baby ${ }^{(5)}$.

The scheduled visit of pregnant women and their companions in the last trimester of pregnancy is a continuity strategy of the care line between services that accompany prenatal care and maternity hospitals. The Federal Law No. 11,634, from December 27, 2007, refers to the right of women to know in advance and to connect with the maternity hospital where, besides giving birth, they will be treated in urgency and emergency situations. The visits which occur during pregnancy provide the presentation of the physical environments of the maternity hospital and the discussion of issues related to the moments to be lived there during hospitalization for childbirth ${ }^{(6)}$.

In this study we observed that the nursing team considered that the guidelines provided for women during visits scheduled in the reference maternity hospital are important. The focus is not restricted to labor and delivery, but they also talk about their rights. When a woman knows her body and she is 
informed from the beginning of her pregnancy about the whole evolution of childbirth, she may experience this moment more smoothly ${ }^{(7)}$.

The obstetric nursing care technologies are based on the understanding of the inseparable bond between culture and human nature in the process of pregnancy, labor and delivery and, moreover, they are built on the principle of minimum intervention ${ }^{(5)}$. From this perspective, the use of health education as a care instrument favors the adhesion of women to less interventionist obstetric practices ${ }^{(8)}$. The educational and guidance actions are essential in the care of women during pregnancy, by favoring the access to information and the exercise of their autonomy. That knowledge is essential for pregnant women to make choices and decide on what they think is best for their labors and for the birth of their children ${ }^{(9)}$.

A study conducted in a teaching hospital found out that the nursing staff of the obstetric unit value and feel identification with the care that meets the subjective needs of pregnant women. These care actions are focused on human relations, focused on the value of emotions and guidelines. Nursing professionals believe that women in the period of giving birth have the expectation to receive information about what happens to them at this stage and about the ways of giving birth. This piece of information contributes to overcome possible fears, anxiety and women's tensions. However, professionals experience challenges related to the working process in the hospital that hinder the establishment of individualized care and the achievement of the goals suggested by public health policies ${ }^{(10)}$.

Therefore, the actions instituted by the Carioca Stork Program contribute to qualify hospital obstetric care, through the improvement of nursing care, of guided tours and of guidance given during these visits. These actions favor the incorporation of rights in relation to the access to reference maternity hospitals and to necessary information for women to have an important role in childbirth, which is indispensable for human assistance.
The Carioca Stork Program was implemented in order to organize and qualify assistance during prenatal, labor and birth in an attempt to solve the problems caused by the uncertainty of reference hospitals and even the refusal of hospitals to receive pregnant women due to lack of vacancies ${ }^{(1)}$, being up to the woman to look for care at another institution. In order to overcome these problems of obstetric care, actions that go beyond the guarantee of service are necessary, but actions that address all the dimensions of comprehensive care and that are based on the rights and needs of pregnant women.

This study indicates that the Carioca Stork Program is an important tool to strengthen the enforcement of rights as advocated in official documents previous to its implementation, such as the Program for Humanization of Prenatal and Birth, established by the Ministry of Health through ordinance GM No. 569/2000 and Law of Companion during labor, delivery and the immediate postpartum period, Law No. 11,108 of April, 72005. It is noteworthy that, in the assistance everyday life, this legal framework that supports the actions for women's rights is still not sufficiently fulfilled in all obstetric services of the country ${ }^{(5)}$. The important role of women in childbirth depends on the respect for citizenship, for rights and for the autonomy of women, which are indispensable to care with technical, humane and ethical competence ${ }^{(9)}$.

The role of obstetric nursing is decisive for the change of the obstetric care model in Brazil, despite the fact that its professional practice is still incipient nationwide. Experiences of inclusion of these professionals in maternity wards, normal delivery centers and birthing center in the cities of Rio de Janeiro and Belo Horizonte have been recognized as important knowledge production spaces and systematization of practices ${ }^{(11)}$.

The World Health Organization recommends the action of obstetric nursing during childbirth, as it believes that this profession is essentially guided towards care and to the importance of the 
physiological aspects of delivery, avoiding unnecessary interventions and contributing to the reduction of maternal mortality rates ${ }^{(12)}$.

The respectful approach of health professionals favors the welcoming and assumes that women should be valued and regarded as people who have rights. Welcoming provides a stronger bond between professionals and patients, and it involves actions, attitudes and behaviors that seek the promotion, maintenance and restoration of health, and human dignity and totality ${ }^{(13)}$. In addition, the adequate creation of a bond with the professional during care promotes women's satisfaction ${ }^{(14)}$, who start to look for this kind of service.

Furthermore, the inclusion of nurses in obstetric care and the implementation of the Carioca Stork program caused the improvement of information for women about their rights, about care technologies offered and about the physiology of labor. Obstetric nurses help to change the focus of assistance on biological aspects, to implement humanized care and to value the orientation of pregnant women during the care process ${ }^{(15)}$.

The reports that expose obstacles to change may be associated with actions previously taken by governments and institutions, for the humanization of care and reduction of interventions during labor and delivery ${ }^{(16)}$.

It should be highlighted that the improvement of obstetric care in municipal maternity hospitals in Rio de Janeiro has been done since the 1990s, such as the adoption of practices of humanized care and the encouragement of the action of obstetric nurses since $1998^{(17)}$. However, its effectiveness is not full yet, due to the persistence of assistance structures and processes of the biomedical model in these institutions. Therefore, the Carioca Stork Program can be considered as one more strategic action to implement the necessary changes in obstetric care in the National Health System.

\section{Final Considerations}

The study revealed that the nursing staff considers that the Carioca Stork program provided improvements in delivery care and qualified the care provided through guided tours to the reference maternity during prenatal care; guidance about labor and the rights provided by the Brazilian legislation; welcoming of pregnant women and encouragement of the humanization of delivery care in local hospitals.

The main repercussions of this program were: the guarantee of women's rights, such as the presence of a companion during labor and childbirth; strengthening of obstetric nursing and, consequently, the promotion of women's satisfaction with the care provided. Thus, the nursing staff realized that women were particularly helped by counting on an interconnected network of services facilitating access and the exercise of rights during childbirth. Similarly, nursing itself was favored when it participated in all the care components of the program.

It should be noted that this study has limitations for being developed in only one municipal maternity hospital and for having contemplated only the perspective of the nursing team, not allowing generalizations in its results. Therefore other investigations are necessary regarding the evaluation of women about the actions instituted by the Carioca Program Stork, as they are the direct beneficiaries and the ultimate reason for health care.

Despite these limitations, the results can support new research on the quality of obstetric care in the public health system and its interfaces with the existing public health policies.

\section{Collaborations}

Lima AEF, Silva LJ and Maia ML contributed to the project design, data collection, analysis and interpretation of results. Pereira ALF contributed to the project design. Zveiter $M$ and Silva TMA contributed to the analysis, drafting, revision and final approval of the version to be published. 


\section{References}

1. Secretaria Municipal de Saúde e Defesa Civil (RJ). Convocação pública para parcerias com Organizações Sociais. Programa Cegonha Carioca. Rio de Janeiro: SMSDC; 2010.

2. Ministério da Saúde (BR). Secretaria de Atenção a Saúde. Humanização do parto e do nascimento. Brasília: Ministério da Saúde; 2014.

3. Ministério da Saúde (BR). Manual prático para a Implementação da Rede Cegonha. [Internet]. 2011 [citado 2014 ago. 25]. Disponível em: http:// www.saude.mt.gov.br/upload/documento/444/ manual-pratico-rede-cegonha-[5B444-090312SES-MT].pdf

4. Bardin L. Análise de conteúdo. São Paulo: Edições 70; 2011.

5. Silva TF, Costa GAB, Pereira ALF. Cuidados de enfermagem obstétrica no parto normal. Cogitare Enferm. 2011; 16(1):82-7.

6. Progianti JM, Pereira ALF, Sento Sé CC. A prática das enfermeiras obstétricas nas emergências vinculadas ao Programa Cegonha Carioca. Rev Enferm UERJ. 2014; 22(6):792-7.

7. Frello AT, Carraro TE, Bernardi MC. Cuidado e conforto no parto: estudos na enfermagem brasileira. Rev Baiana Enferm. 2011; 14(2):17384.

8. Progianti JM, Costa RF. Práticas educativas desenvolvidas por enfermeira: repercussões sobre vivências de mulheres na gestação e no parto. Rev Bras Enferm. 2013; 65(2):257-63.

9. Pereira ALF, Bento AD. Autonomia no parto normal na perspectiva das mulheres atendidas na casa de parto. Rev Rene. 2011; 12(3):471-7.
10. Pieszak GM, Terra MG, Neves ET, Pimenta LF, Padoin SMM, Ressel LB. Nursing professionals perceptions on care at a birthing center. Rev Rene. 2013; 14(3):568-78.

11. Gomes MASM. Compromisso com a mudança. Cad Saúde Pública. 2014; 30(Supl. 1):41-2.

12. Vieira BDG, Moura APV, Alves VH, Rodrigues DP. A prática dos enfermeiros obstetras egressos da especialização da escola Anna Nery. Rev Enferm UERJ. 2012; 20 (esp.1):579-84.

13. Nascimento NM, Progianti JM, Novoa RI, Oliveira TR, Vargens OMC. Tecnologias não invasivas de cuidado no parto realizadas por enfermeiras: a percepção de mulheres. Esc Anna Nery. 2010; 14 (3):456-61.

14. D’Orsi E, Brüggemann OM, Diniz CSG, Aguiar JM, Gusman CR, Torres JA et al. Desigualdades sociais e satisfação das mulheres com o atendimento ao parto no Brasil: Estudo nacional de base hospitalar. Cad Saúde Pública. 2014; 30(Supl.1):154-68.

15. Gomes ML, Moura MAV, Souza IEO. Obstetrical practice by nurses in instiutional childbirth: a possibility for emancipatory knowledge. Texto Contexto Enferm. 2013; 22(3):763-71.

16. Mouta RJO, Progianti JM. Estratégias de luta das enfermeiras da Maternidade Leila Diniz para implantação de um modelo humanizado de assistência ao parto. Texto Contexto Enferm. 2009; 18(4):731-40.

17. Progianti JM, Porfírio AB. Participação das enfermeiras no processo de implantação de práticas obstétricas humanizadas na Maternidade Alexander Fleming (1998-2004). Esc Anna Nery. 2012; 16 (3):443-50. 